\title{
テルミサルタン錠との一包化によりアスピリン腸溶錠は 成分量および溶出率が低下する配合変化を起こす
}

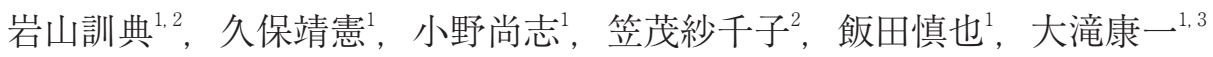 \\ 山田峻史 ${ }^{1}$, 安達知輝 ${ }^{1}$, 福土将秀 ${ }^{1}$, 粟屋敏雄 ${ }^{1,4}$, 田浐嘉一 ${ }^{* 1,2}$ \\ 旭川医科大学病院薬剂部 1 , 旭川医科大学病院臨床研究支援センター ${ }^{2}$ \\ 北海道科学大学薬学部薬物治療学分野, 市立旭川病院薬剤科 ${ }^{4}$
}

\section{The Physical Incompatibilities of Enteric-coated Aspirin Tablets with Non-coated Telmisartan Tablets in One-dose Packages Lead to a Decreased Content and Dissolution Rate of Aspirin}

\author{
Kuninori Iwayama ${ }^{1,2}$, Yasunori Kubo ${ }^{1}$, Takashi Ono ${ }^{1}$, Sachiko Kasamo ${ }^{2}$, Shinya Iida ${ }^{1}$, Ko-ichi Ohtaki ${ }^{1,3}$, \\ Takeshi Yamada ${ }^{1}$, Tomoki Adachi ${ }^{1}$, Masahide Fukudo ${ }^{1}$, Toshio Awaya ${ }^{1,4}$ and Yoshikazu Tasaki ${ }^{* 1,2}$ \\ Department of Hospital Pharmacy \& Pharmacology, Asahikawa Medical University ${ }^{1}$, \\ Clinical Research Support Center, Asahikawa Medical University ${ }^{2}$, \\ Department of Pharmacology \& Therapeutics, Faculty of Pharmacy, Hokkaido University of Science 3 , \\ Department of Pharmacy, Asahikawa City Hospital ${ }^{4}$ \\ $\left[\begin{array}{l}\text { Received April 14, } 2018 \\ \text { Accepted }\end{array}\right]$
}

One-dose packages are useful for managing complicated medication regimens for older patients. We experienced a case of Bayaspirin ${ }^{\circledR}$ tablet $100 \mathrm{mg}$ (BA) and Micardis ${ }^{\circledR}$ tablet $40 \mathrm{mg}$ (Mic 40) that were fused in a one-dose package at the time of medicine reconciliation. To our knowledge, there are no previous reports assessing the quality of these tablets caused by this physical incompatibility. Therefore, we aimed to examine this phenomenon and its impact on the drug compositions, as well as to identify the mechanisms.

$\mathrm{BA}$ and Mic 40 in one-dose packages were stored at $30^{\circ} \mathrm{C} / 75 \%$ relative humidity $(\mathrm{RH})$ or $93 \% \mathrm{RH}$ condition for 1 week. The stability evaluations were performed on appearance change, hardness, content, and dissolution rate. The active ingredients in each tablet were investigated to determine the mechanisms.

Mic 40 showed changes in appearance and hardness, while BA showed a changed appearance, and reduced content and dissolution rate. The enteric coatings of BA and the additive in Mic 40 had an influence on the mechanism of incompatibility.

Mic 40 contains meglumine, which is hygroscopic and deliquescent. Therefore, meglumine absorbs moisture and becomes a basic solution. Methacrylic acid copolymer LD dissolved in this basic solution results in adhesion with Mic 40 and leads to a decrease in both the content and the dissolution rate in BA. This is the first study to analyze the physical incompatibilities of enteric-coated aspirin tablets with non-coated telmisartan tablets in one-dose packages and provides useful information for clinical practice.

Key words — one-dose package, incompatibility, aspirin, telmisartan

\section{緒言}

一包化調剂は，服用時点が同じ複数の薬剤をまと めて 1 袋にしておく方法であり, 薬剤の紛失および press through package（PTP）誤嚥事故を防止する
だけでなく, 患者のアドヒアランス向上にも有効で ある. ${ }^{1)}$ 通常一包化された錠剂同士が保存中に結合し てしまうことはないが, 旭川医科大学病院における 入院時の持参薬確認時において, バイアスピリン® 錠 $100 \mathrm{mg}$ (BA) とミカルディス ${ }^{\circledR}$ 錠 40 mg (Mic 40)

\footnotetext{
*テ 078-8510 北海道旭川市緑が丘東 2 条 1 丁目1-1
} 

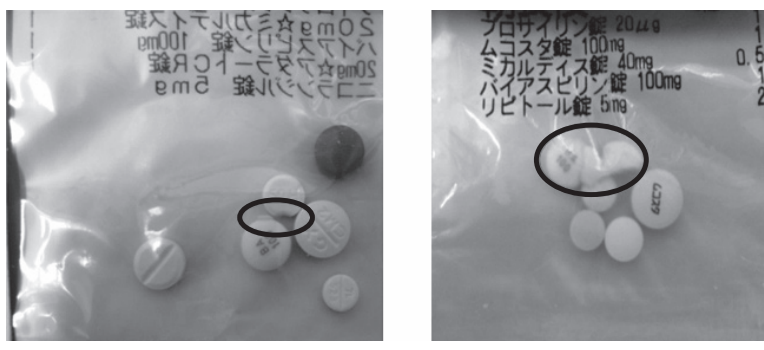

図 1 持参薬確認業務時に発見された配合変化事例

が分包内で融合（配合変化）している事例を複数 回経験した（図 1). 錠剂同士が融合するには，そ の成分または表面上の物質の関与が考えられる。

$\mathrm{BA}$ の有効成分はアセチルサリチル酸 (acetylsalicylic acid: ASA) で, 非ステロイド性抗炎 症薬 (non-steroidal anti-inflammatory drugs: NSAIDs) の 1 つであり，解熱鎮痛作用以外に抗血小板作用を 有している，本剤は，局所刺激作用による胃十二指 腸潰瘍，胃出血などの有害事象を軽減する目的で腸 溶錠になっているが，腸溶性コーティング剂として メタクリル酸コポリマーLD が使用されている（バイ エル薬品株式会社，バイアスピリン®錠 $100 \mathrm{mg}$, 医 薬品インタビューフォーム (IF), 2014 年 3 月作成 (第 10 版))。このメタクリル酸コポリマーLDは，その他 の腸溶性製片においても広く使用されている.

一方 Mic 40 は，コーティングされていない素錠で あり, アンギオテンシン II 受容体拮抗薬（angiotensin II receptor blocker: ARB）に分類される高血圧症治 療薬である。ほかに $20 \mathrm{mg}$ (Mic 20）と $80 \mathrm{mg}$ （Mic 80）の規格が存在するが，これらの製剂のうち Mic 20 および Mic 40 は素錠, Mic 80 がフィルムコーティ ング錠となっており，規格により異なっている（日 本ベーリンガーインゲルハイム株式会社, ミカル ディス ${ }^{\circledR}$ 錠，IF，2015 年 4 月作成（改訂 20 版)). また有効成分であるテルミサルタン（telmisartan: TEL）には，吸湿性はないが素錠である Mic 20 お よび Mic 40 は，無包装状態かつ高湿度条件下に保 存することで, 吸湿し潮解することが知られている.

一包化調剤を行う場合に，無包装状態での錠剤 の安定性に関する情報を把握しておくことは重要 である。しかし，錠剤の一包化による配合変化に 関する報告はほとんどなく，これまでに調べた限 りに拈いて知られているのは，オルメテック®錠
との一包化により，メトホルミン錠が変色するこ とと（第一三共株式会社，オルメテック ${ }^{\circledR}$ 錠，IF, 2015 年 12 月作成 (第 20 版)), メトホルミン錠と の一包化により, クアゼパム錠が退色すること 2 である。いずれも外観に関する検討であり, 配合 変化後の安定性に及ぼす影響については明らかに されていない，金田らは，一包化調剂後の配合変 化に対する薬剂師の認知度は低く, 臨床現場にお いて十分に周知されていないことを報告してい る. ${ }^{3)}$ 従って今回のような配合変化した錠剤の安 定性や発生メカニズムを明らかにすることは，一 包化調剤における適切な錠剤の組み合わせを知る 上で重要な情報となる。そのため本研究では, 配 合変化した BA および Mic 40 の安定性評価と配 合変化の発生メカニズムについて検討した。

\section{方 法}

\section{1. 試薬}

ASA 標準試薬，サリチル酸（salicylic acid: SA） 標準試薬，メタノール，リン酸二水素カリウム, リン酸水素二ナトリウム無水物およびエタノール は，和光純薬工業(株) (大阪) から購入した. TEL 標準試薬，オイドラギッド® L-100-55（乾燥メタク リル酸コポリマーLD，製造番号 B151004038），日 本薬局方ゼラチンカプセルは, それぞれ東京化成 工業(株) (東京), エボニック・ジャパン (株) (大 阪), 小林カプセル (株) (兵庫) から購入した。す べての試薬は特級品を用いた。

\section{2. 対象薬剈}

BA（製造番号 5476），Mic 40 (製造番号 489409)， バファリン®配合錠 A $81 \mathrm{mg}$ (製造番号 72671), パキシル ${ }^{\circledR} \mathrm{CR}$ 錠 $12.5 \mathrm{mg}$ (製造番号 $\left.\mathrm{MT} 3 \mathrm{H}\right)$ ， カル ナクリン® 錠 50 IU（製造番号 FL04201）は，それ ぞれバイエル薬品(株) (大阪), 日本ベーリンガー インゲルハイム(株) (東京), エーザイ(株) (東京), グラクソ・スミスクライン(株) (東京), (株)三和 化学研究所（愛知）から購入した.

\section{3. 安定性評価用サンプルの作製}

BA と Mic 40 を 1 錠ずつ互いに接触した状態で 
セロポリ紙（(株)トーショー, 東京）を用いて一 包化し, 恒温恒湿器 (IG47M, ヤマト科学(株), 東京）内に $30^{\circ} \mathrm{C} / 75 \%$ 相対湿度（relative humidity： $\mathrm{RH} ）$ また $30^{\circ} \mathrm{C} / 93 \% \mathrm{RH}$ の条件下で 1 週間保存 した。このうち融合したもの（BA+ Mic 40）を 安定性評価に用いた。無包装状態の影響を評価す るため, BAを単独で一包化した群（BA 単独） も同様の条件下で保存した．またPTP シートか ら取り出した直後の BA をコントロールとした。

\section{4. 外観変化}

各条件下で 1 週間保存した後の外観変化を肉眼 的観察により評価した，外観変化の画像は，USB 接続デジタル顕微鏡（3R-MSUSB201, スリーアー ルソリューション(株), 福岡) により取得した。

\section{5. 重量測定}

BA および Mic 40 の重量は, 精密天秤（メトラー・ トレド(株)，東京）で測定した。いずれも各群 6 回 ずつ繰り返し，PTPから取り出した各錠剤の重量 をコントロールとした時の重量変化率を求めた。

\section{6. 硬度測定}

錠剤の硬度は，モンサント型硬度計（萱垣医理科 工業(株)，東京）を用いて測定した. いずれも各群 6 回ずつ繰り返し, PTPから取り出した各錠剤の硬 度をコントロールとした時の硬度変化率を求めた。

\section{BA の ASA および SA 含量}

$30^{\circ} \mathrm{C} / 75 \% \mathrm{RH}$ 条件下で保存後の BA 1 錠粉砕 し, メタノール $30 \mathrm{~mL}$ で溶解した。 その後, 精 製水を $100 \mathrm{~mL}$ まで加えた溶液を $0.45 \mu \mathrm{m}$ メンブ レンフィルター（コスモナイスフィルター，日本 ミリポア，京都）でろ過したものを含量試験用の サンプルとした.いずれも各群 6 回ずつ繰り返し, PTPから取り出したBAの ASA 含量をコントロー ルとした時の含量変化率を求めた.さらに ASA の分解生成物である SA も併せて測定した.

\section{BA の溶出試験}

溶出試験は，第 17 改正日本薬局方一般試験法に 収載されている第 2 法 (回転パドル法)に準拠した。
試験には 6 連溶出試験器 (DT-610, 日本分光(株), 東京）およびフラクションシステム（DIS-422）を 使用した．各ベッセル（反応容器）に溶出試験第 1 液（pH 1.2）または第 2 液（pH 6.8）を $900 \mathrm{~mL}$ 加 えて, 温度は $37 \pm 2^{\circ} \mathrm{C} に$ 保った。 パドル回転数は $75 \mathrm{rpm} / \mathrm{min}$, 溶出液の採取時間は $0,15,30,60$ お了 よび 120 分とした. 採取した溶出液は $0.45 \mu \mathrm{m}$ フィ ルターを通して溶出試験用のサンプルとした．各 ベッセルには，採取されると同時に同量の溶出試 験液を自動補充されるように設定した。

\section{ASA および SA の定量}

薬物の定量は, 高速液体クロマトグラフィー (high performance liquid chromatography: HPLC) で実施した，含量試験および溶出試験で得られた サンプル中の ASA およびSA の測定には, HPLC システム (LC-20AD ポンプ, SPD-M20A UV 検出器, SIL-20AC オートサンプラー, CTO-20A カラムオー ブン)，((株)島津製作所，京都）を使用した。 カラ ムは, Wakopuresil-II 5C18 RS $(3.0 \mathrm{~mm} \times 150 \mathrm{~mm}$, $4.6 \mu \mathrm{m}$, 和光純薬工業), 流速は $0.5 \mathrm{~mL} / \mathrm{min}$, カラ ム温度は $40^{\circ} \mathrm{C} て ゙$ 行った. ASA および SA の測定波 長は $295 \mathrm{~nm}$, 移動相は, pH 2.0 に調節した $2.5 \mathrm{mM}$ リン酸二水素カリウムとメタノールを $3: 2$ で調 製した溶液を使用した。ASA および SAの検量線 は，それぞれ 1- $200 \mu \mathrm{g} / \mathrm{mL} ， 0.1-25 \mu \mathrm{g} / \mathrm{mL}$ の範囲 で作成した．溶出時間 60 および 120 分における ASA 分解率は, 各サンプル中の SA を ASA 量へ 換算して求めた $(\mathrm{ASA}$ 分解率 $=$ 络サンプル中の SA から換算した ASA 量/溶出した ASA 量 + SA から換算した ASA 量 $\} \times 100)$.

\section{Mic 40 の有効成分 TEL が配合変化に及ぼす 影響}

TEL 試薬または粉砕した Mic 40, Mic 80 と BA を一包化し, $30^{\circ} \mathrm{C} / 75 \% \mathrm{RH}$ の条件下で 1 週間保存 した. 保存後の外観変化は, 肉眼的観察により評 価した。ささらに添加物の影響をみるために $\mathrm{pH}$ を測 定した. TEL 試薬および粉砕した Mic 40 は，いず れも $0.4 \mathrm{mg} / \mathrm{mL}$ の濃度になるように精製水で溶解 した. pH の測定には, pHメーター（pH METER F51，(株)堀場製作所，京都）を使用した。いずれ 
も各群 6 回ずつ繰り返し行った

\section{ASA およびその製剤による配合変化の検討}

コーティング剂の影響を検討するため，ASA 製 凨で素錠のバファリン®配合錠 A81 と Mic 40 の配 合変化と BA で使用されている腸溶性コーティン グ剤のメタクリル酸コポリマーLD と Mic 40 との 配合変化を検討した，腸溶性コーティング剤は， オイドラギッド®L100-55 $15 \mathrm{~g}$ にエタノール $100 \mathrm{~mL}$ を加え 3 時間以上溶解して調製した。 日本薬局方 ゼラチンカプセルに腸溶性コーティングを実施し， 十分に乾燥した後にMic 40 と一包化を行い, $30^{\circ} \mathrm{C} / 75 \% \mathrm{RH}$ の条件下で 1 週間保存した。さらに 同じ条件にて BA と同じメタクリル酸コポリマー LDがコーティング剤として使用されている腸溶 性製郕のパキシル ${ }^{\circledR} \mathrm{CR}$ 錠 $12.5 \mathrm{mg}$ ，カルナクリン® 錠 50 IU と Mic 40 との配合変化も検証した．保存 後の外観変化は，肉眼的観察により評価した。

\section{2. 評価および統計解析}

評価については，日本病院薬郕師会学術第 5 小委員会「錠剤・カプセル剂の無包装状態での 安定性試験法について (答申)」に従って行った （表 1）。外観変化を除く各デー夕は，平均 \pm 標準 偏差（ $n=3 \sim 6 ）$ で示した。重量変化率, SA 含量, ASA 溶出率および分解率の統計解析には，一元配 置分散分析 (one-way analysis of variance: one-way ANOVA）後, Bonferroni の多重比較検定を用い て $P<0.05$ を有意差ありとした。すべての評価終 了後の BA および Mic 40 の総合判定は，「変化な し」,「変化あり（規格值内）」,「変化あり（規格外）」 で判断した.

\section{結果}

\section{1. 外観変化}

$30^{\circ} \mathrm{C} / 75 \% \mathrm{RH}$ 条件下の $\mathrm{BA}$ および $\mathrm{Mic} 40$ は接着 （融合）していた（図 2A）が，品質は外観上判断

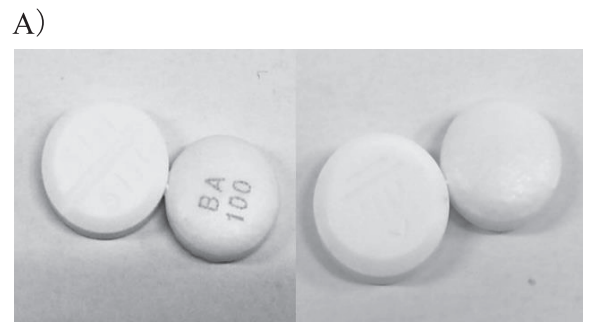

B)

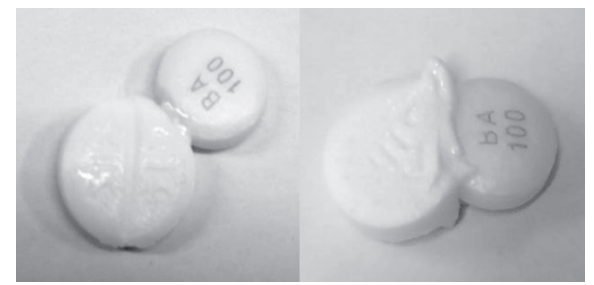

C)

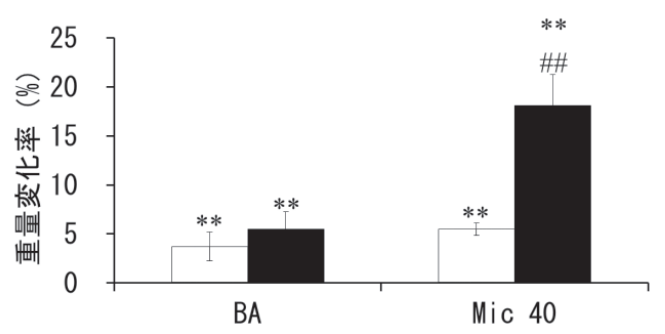

図 2 各種条件下で 1 週間保存した後の外観変化と 重量増加率

BA およびMic 40 は，接触した状態で A : $30^{\circ} \mathrm{C} / 75 \% \mathrm{RH}, \mathrm{B}$ ： $30^{\circ} \mathrm{C} / 93 \% \mathrm{RH}$ 条件下にて 1 週間保存した後の外観変化, C : 重 量変化率を示している. 重量変化率のデータはいずれも平均 土標準偏差（n=6）で表している。 $\square 30^{\circ} \mathrm{C} / 75 \% \mathrm{RH}, \square 30^{\circ} \mathrm{C} /$ $93 \%$ RH. $* * P<0.01$ vs コントロール, \#\# $P<0.01$ vs $30^{\circ} \mathrm{C} /$ $75 \%$ RH. one-way factorial ANOVA followed by the Bonferroni's test. BA: バイアスピリン ${ }^{\circledR}$ 錠, Mic 40: ミカルデイス ${ }^{\circledR}$ 錠 $40 \mathrm{mg}$.

表 1 判定基準

\begin{tabular}{|c|c|c|c|c|c|}
\hline & 外観 & 硬度 & 含量 & 崩壊性 & 溶出性 \\
\hline 変化なし & 外観変化なし & 変化率 < $30 \%$ & 低下率 < 3\% & 規格值内 & 規格值内 \\
\hline 変化あり（規格内） & $\begin{array}{c}\text { わずかな色調変化等を } \\
\text { 認めるが, 品質上 } \\
\text { 問題とならない程度 }\end{array}$ & $\begin{array}{c}\text { 変化率 }>30 \% \\
\text { かつ } \\
\text { 硬度 }>2.0 \mathrm{kgf}\end{array}$ & $\begin{array}{c}\text { 低下率>3\% } \\
\text { かつ } \\
\text { 規格值内 }\end{array}$ & - & - \\
\hline 変化あり（規格外） & $\begin{array}{c}\text { 形状変化や著しい } \\
\text { 色調変化がある }\end{array}$ & $\begin{array}{c}\text { 変化率 }>30 \% \\
\text { かつ } \\
\text { 硬度 }<2.0 \mathrm{kgf}\end{array}$ & 規格值外 & 規格值外 & 規格值外 \\
\hline
\end{tabular}

【総合評価】変化なし：すべての測定項目において, 変化を認めなかった場合. 変化あり (規格値内)：いずれかの測定項目において,「規 格内」の変化を認めた場合．変化あり（規格值外）：いずれかの測定項目において，「規格外」（規格を冕脱する）の変化を認めた場合. 
できなかった。しかしながら， $30^{\circ} \mathrm{C} / 93 \% \mathrm{RH}$ 条件 下では同様に接着（融合）し，BA では腸溶性コー ティング部の変色, Mic 40 は著しい形状変化が見 られたため, どちらも「変化あり (規格外)」となっ た（図 2B）。どちらの条件下でも接触していた錠 剤同士はすべて接着（融合）していた。

\section{2. 重量変化率}

$\mathrm{BA}$ の重量変化率は, $30^{\circ} \mathrm{C} / 75 \% \mathrm{RH}$ および $30^{\circ} \mathrm{C} /$ $93 \%$ RH の条件において $3.7 \pm 1.7 \%, 5.5 \pm 1.8 \%$ とコントロールと比較して有意に増加した。また Mic 40 においても $4.9 \pm 0.6 \% ， 18.1 \pm 3.2 \%$ と重 量変化率が有意に増加し， $30^{\circ} \mathrm{C} / 93 \% \mathrm{RH}$ における 重量変化率が最も顕著であった（図 2C).

\section{3. 硬度}

BA では，どちらの保存条件下においても「変 化なし」であった。一方 Mic 40 は $30^{\circ} \mathrm{C} / 75 \% \mathrm{RH}$ で保存した際の硬度は 7.3 から $2.5 \mathrm{kgf}$ に減少し, 「変化あり（規格内）」の判定となった.さらに $30^{\circ} \mathrm{C} / 93 \% \mathrm{RH}$ においては, 硬度の測定が不可能で あるほど錠剤が軟化していたため「変化あり（規
格外)」であった（図 2B，表 2)。そのため以降 の安定性評価は, BAに着目して行った。

\section{4. 含量}

コントロールにおける ASA 含量は $101.7 \pm 2.5 \mathrm{mg}$ であり，規格適合品であった． $30^{\circ} \mathrm{C} / 75 \% \mathrm{RH}$ 条件 下で 1 週間保管した BA 単独における ASA 含量 の低下は，見られなかった，しかしながら，BA+ Mic 40 ではコントロールょり 9.2\%の含量低下を 示したため「変化あり (規格外)」であった。さ らにSAを測定したところ，コントロールと BA 単独では, 統計学的有意差は見られなかったが, BA + Mic 40 では有意にSA が増加した（表 3）。

\section{5. 溶出試験}

溶出試験第 1 液において， $30^{\circ} \mathrm{C} / 75 \% \mathrm{RH}$ で保管 したすべてのサンプルでASA の溶出は見られな かった（図 3A)。しかしながら，30ㄷ / $93 \% R H$ で は，コントロールおよび BA 単独では ASA の溶 出は見られなかったものの, BA + Mic 40 では ASA が溶出した（図3B）.

溶出試験第 2 液において, $30^{\circ} \mathrm{C} / 75 \% \mathrm{RH}$ で保管

表 2 硬度変化

\begin{tabular}{ccccc}
\hline \hline & 単位 & コントロール & $30^{\circ} \mathrm{C} / 75 \% \mathrm{RH}$ & $30^{\circ} \mathrm{C} / 93 \% \mathrm{RH}$ \\
\hline \multirow{4}{*}{$\mathrm{BA}$} & $\mathrm{kgf}$ & $6.5 \pm 0.5$ & $5.9 \pm 0.5$ & $4.9 \pm 0.7$ \\
& (範囲) & $(5.3-7.1)$ & $(5.3-6.6)$ & $(4.0-5.8)$ \\
& $\%$ & - & -8.7 & -24.1 \\
& 判定 & - & 変化なし & 変化なし \\
\multirow{3}{*}{ Mic 40} & $\mathrm{kgf}$ & $7.3 \pm 0.7$ & $2.5 \pm 0.4$ & $\mathrm{ND}$ \\
& (範囲) & $(6.3-8.2)$ & $(1.8-2.9)$ & - \\
& $\%$ & - & -65.6 & 変化あり (規格外) \\
\hline
\end{tabular}

上段の $\mathrm{kgf}$ は，硬度の平均 \pm 標準偏差 $(\mathrm{n}=6)$ で示している. 下段の\%は，コントロールを基準とした 時の変化率を表している. ND: not detected. BA: バイアスピリン® 錠, Mic 40: ミカルデイス ${ }^{\circledR}$ 錠 $40 \mathrm{mg}$.

表 3 含量変化

\begin{tabular}{|c|c|c|c|c|}
\hline $30^{\circ} \mathrm{C} / 75 \% \mathrm{RH}$ & 単位 & "コントロール & BA 単独 & BA+Mic 40 \\
\hline \multirow{3}{*}{ ASA } & $\mathrm{mg}$ & $101.7 \pm 2.5$ & $103.9 \pm 3.9$ & $92.4 \pm 4.1$ \\
\hline & $\%$ & - & 2.1 & -9.2 \\
\hline & 判定 & - & 変化なし & 変化あり（規格外） \\
\hline \multirow{2}{*}{ SA } & $\mathrm{mg}$ & $3.0 \pm 1.1$ & $3.8 \pm 0.3$ & $4.2 \pm 0.2^{\mathrm{a})}$ \\
\hline & $\%$ & - & 27.0 & 42.4 \\
\hline \multicolumn{5}{|c|}{ 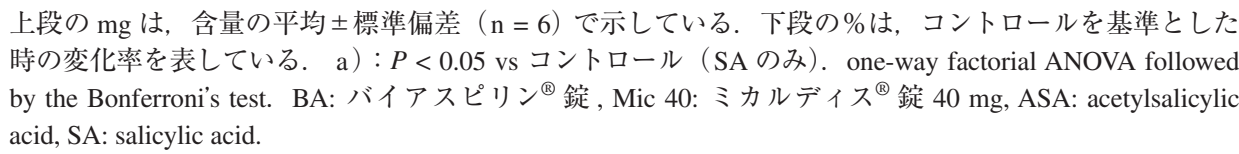 } \\
\hline
\end{tabular}


したすべてのサンプルで時間依存的に ASA の溶 出率は増加した．コントロールにおいては, ASA の溶出率が溶出時間 120 分の時点で $93.4 \pm 2.8 \%$ を示した。BA 単独では，溶出時間 30，60 分に おいてコントロールと比較して有意に低下したも

A)

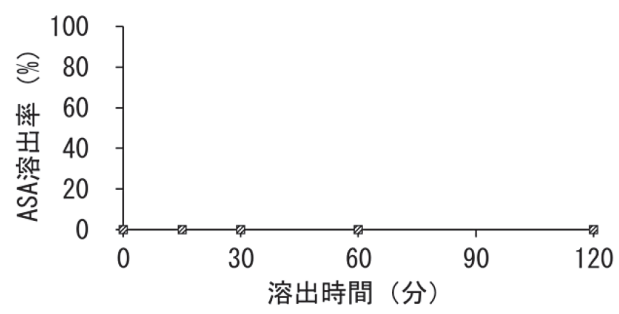

B)

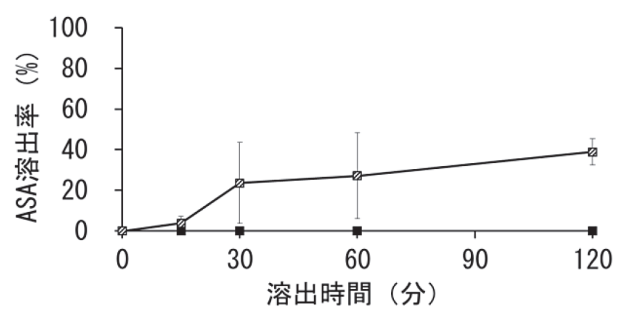

C)

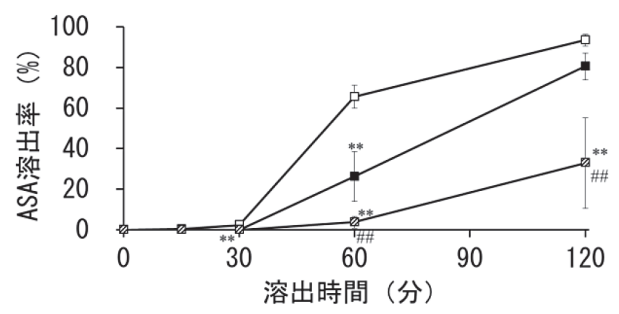

D)

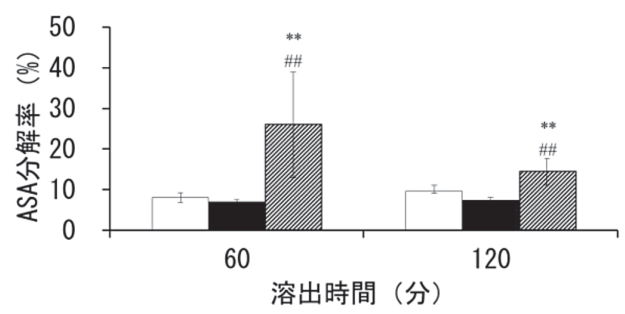

図 3 溶出試験

$\mathrm{A}: 30^{\circ} \mathrm{C} / 75 \% \mathrm{RH}, \quad \mathrm{B}: 30^{\circ} \mathrm{C} / 93 \% \mathrm{RH}$ 条件下で 1 週間保存後の溶 出試験第 1 液 $(\mathrm{pH}$ 1.2) に打ける ASA 溶出率を示している. C : $30^{\circ} \mathrm{C} / 75 \% \mathrm{RH}$ 条件下で 1 週間保存後の溶出試験第 2 液 $(\mathrm{pH} 6.8)$ における ASA 溶出率抄よびD：60，120 分に打ける ASA 分解 率を示している。デー夕はいずれも平均土標準偏差 $(\mathrm{n}=3 \sim 6)$

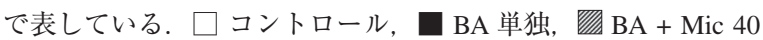
を示している. ***P<0.01 vs コントロール，\#\#P<0.01 vs BA 単独. one-way factorial ANOVA followed by the Bonferroni's test. ASA: acetylsalicylic acid, BA: バイアスピリン ${ }^{\circledR}$ 錠, Mic 40: ミカ ルデイス ${ }^{\circledR}$ 錠 $40 \mathrm{mg}$.
のの, 試験終了時点では $80.5 \pm 6.6 \%$ を示し, こ の時点での統計学的有意差は見られなかったため 「変化なし」となった。一方, BA+ Mic 40 の ASA 溶出率は, 溶出時間 30 分でコントロールと 比較して有意に低下した。さらに 60 および 120 分ではそれぞれ ASA 溶出率が $3.8 \pm 3.0 \%, 32.9$ 土22.3\%であり，コントロールおよび BA 単独と 比較して有意に低下し，「変化あり（規格外）」で あった（図3C）。

さらに, ASAの分解率を算出したところ，溶 出時間 60 分におけるコントロールは $8.1 \pm 1.1 \%$, $\mathrm{BA}$ 単独では $7.0 \pm 0.6 \%$ であり統計学的有意差は 見られなかった。一方 BA+Mic 40 は26.0土 $13.0 \%$ であり，コントロール，BA 単独と比較し て有意に大きかった。溶出時間 120 分における ASA 分解率も同様に BA + Mic 40 で有意に大き かった（図 3D）.

\section{Mic 40 の有効成分および製剤が配合変化に 及ぼす影響}

試薬の TEL と BA では配合変化は示さず，残 存した TEL サンプルにも大きな変化は見られな かった（図 4A）。一方，錠剤を粉砕した Mic 40 と BAでは配合変化が見られた，さらに粉砕した

A)
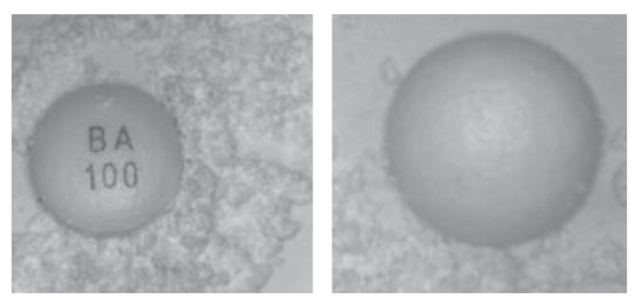

B)
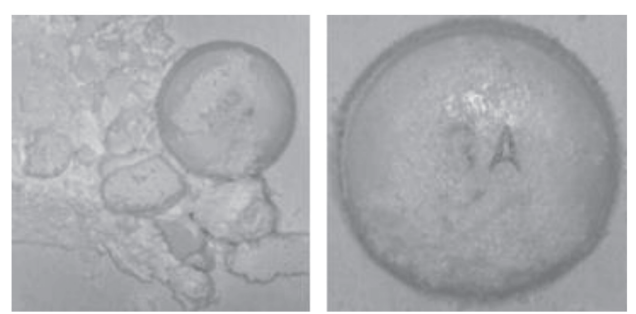

図4 Mic 40 の有効成分および製剤が配合変化に及 ぼす影響

A：TEL 試薬と BA, B ：Mic 40（粉硡）と BA を一包化し, $30^{\circ} \mathrm{C} /$ $75 \% \mathrm{RH}$ 条件下にて 1 週間保存した際の外観変化を示している. Mic 40: ミカルディス ${ }^{\circledR}$ 錠 $40 \mathrm{mg}, \mathrm{TEL}:$ テルミサルタン, BA: バイ アスピリン ${ }^{\circledR}$ 錠. 
Mic 40 は固結した状態であった（図 4B）.

次いで $\mathrm{pH}$ を測定したところ TEL 試薬は $6.4 \pm$ 0.3 と弱酸性〜中性を示し, Mic 40 では $9.7 \pm 0.1$ と塩基性を示した。

\section{ASA およびその製剤による配合変化の検討}

有効成分を含む素錠であるバファリン®配合錠 A81 と Mic 40 では配合変化は見られなかったが, 腸溶性コーティング処理したゼラチンカプセルと Mic 40 では配合変化を示した（図 5A）。また腸 溶性コーティング未処理のゼラチンカプセルにお いて配合変化は見られなかった。一方，メタクリ ル酸コポリマーLDを含有する医薬品であるパキ シル ${ }^{\circledR} \mathrm{CR}$ 錠 $12.5 \mathrm{mg}$ およびカルナクリン ${ }^{\circledR}$ 錠 $50 \mathrm{IU}$ と Mic 40 の配合変化試験を実施したところ，い ずれも配合変化を示した（図 5B，C)。特にカル ナクリン®錠 $50 \mathrm{IU}$ の場合, 腸溶性コーティング

\section{A)}

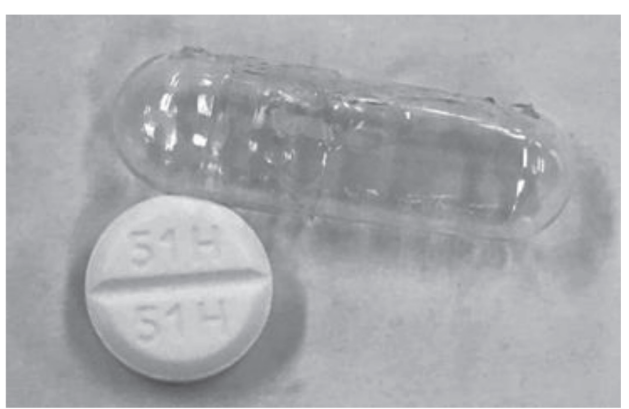

B)

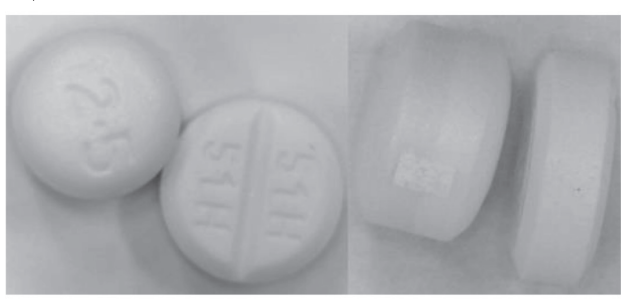

C)

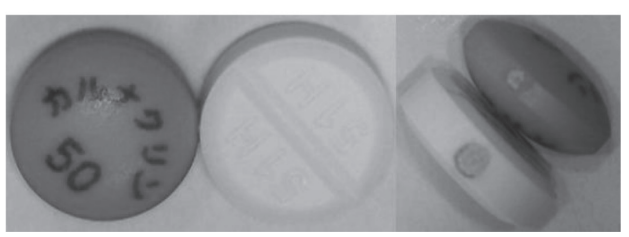

図 5 BA の有効成分抒よび製剂が配合変化に及ぼす 影響

A：メタクリル酸コポリマーLD でコーティングした日本薬局 方カプセルと Mic 40, B : パキシル ${ }^{\circledR} \mathrm{CR}$ 錠 $12.5 \mathrm{mg}$ と Mic 40, C : カルナクリン ${ }^{\circledR}$ 錠 $50 \mathrm{IU}$ と Mic 40 を接触した状態で $30^{\circ} \mathrm{C} /$ $75 \% \mathrm{RH}$ 条件下にて 1 週間保存した後の外観変化を示している. Mic 40: ミカルデイス田錠 $40 \mathrm{mg}$.
部の剥離抒よびMic 40 への着色が見られ, 配合 変化が明らかであった.

\section{考察}

本研究では, 以下の 2 点について明らかにした. 1 点目は, Mic 40 との配合変化を生じた BA は, ASA から SAへの加水分解が促進され, ASA 含量 および溶出率の低下を示すこと, 2 点目は BA と Mic 40 の配合変化は腸溶性コーティング剂であるメ タクリル酸コポリマーLD と Mic 40 製剂に含有する 添加物の吸湿性と塩基性により生じることである.

BA および Mic 40 の錠剂同士の配合変化後の安 定性については，外観変化はいずれの保存条件で も見られたが，特に $30^{\circ} \mathrm{C} / 93 \% \mathrm{RH}$ においてはBA のコーティング部の変色, Mic 40 の著しい形状 変化を示していたこと（図2A，B）, また室温で 1 週間保存したサンプルでは外観変化を認めな かった（data not shown）ことから配合変化には 高い湿度の影響が考えられた．さらに Mic 40 の 重量変化率が最も高く (図 2C), 硬度は測定不 能となるまで軟化していたこと（表 2), 無包装 状態の Mic 40 は, 吸湿性および潮解性を示すこ とが知られていることから高い湿度により Mic 40 が水分を吸収していることが考えられた.

含量試験においては, 融合した BA + Mic 40 で はASAの含量が低下し, SA が増加していること が明らかとなっている（表 3)。 また溶出試験第 1 液に拈いて BA + Mic 40 では, ASA が溶出して おり（図3B），融合したことにより，BAの腸溶 性製剂としての役割が失われていることが考えら れた．さらに溶出試験第 2 液においては $\mathrm{BA}+\mathrm{Mic}$ 40 の溶出率は低下し, SA が増加した（図 3C, D). BA はアルカリ性薬椷と簡易懸濁法を行うことで 成分量が低下し，SA が増加することが報告 ${ }^{4)} さ$ れているため, Mic 40 が高湿度のなかで存在す ることにより微量の塩基性水溶液が生成され ASA がSAへの加水分解が促進されたと考元られ た. BA は高温状態 $\left(60^{\circ} \mathrm{C}\right.$ で 4 週間保存 $)$ で保存 することによって腸溶性フィルムが変性し, ASA の放出を低下させ，SA の増加が報告 ${ }^{5)}$ されてい ることから本研究における配合変化後の溶出率の 
低下は，腸溶性コーティング剤の変性によると考 えられる，安定性試験項目のうち，BAでは含量 および溶出性が低下したため「変化あり(規格外)」 となり, 総合判定も「変化あり (規格外)」となっ た．今回の研究によりこのように錠剤同士が融合 するような配合変化を生じた製剤は，使用するべ きではないことが明らかとなった。

次に錠剂同士の配合変化の発生メカニズムにつ いて特にどのような物質が関与しているかについ て検討した. Mic 40 の変性に影響を与える因子と してはその製剤に含まれている物質が影響を及ぼ していることが明らかとなった（図 4A，B）。さ らに原薬の TEL と製剤の Mic 40 では水に溶解し た時の $\mathrm{pH}$ が大きく異なっており，製剂で使用さ れている添加物の影響が示唆された．Mic 40 で使 用されている 5 種類の添加物のうち, 吸湿性を示 すものはメグルミンのみであり, かつ $\mathrm{pH} 11$ 程度

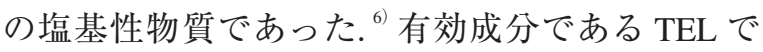
吸湿性を示さないことから，Mic 40 側の因子とし てメグルミンが関与している可能性が最も高い.

一方で BA 側の変性に影響を与える因子とし て，有効成分ではなく，腸溶性コーティング剤が 原因であると考えられた（図 5A）。BA の腸溶性 コーティング剂として使用されているメタクリル 酸コポリマーLD を含有する腸溶性製剤は, Mic 40 との配合変化が見られた（図 5B, C) ことから， 高湿度条件下で保存されることにより， Mic 40 が吸湿・潮解することで微量の塩基性溶液が産生 され，メタクリル酸コポリマーLD は塩基性物質 により溶解し，粘性を示すため錠剤同士の融合と いう配合変化が生じたと推察される。配合変化が 進行することにより ASA 含量や溶出率の低下が 生じると考えられた。

一包化された薬剤の場合, 長期に処方されるこ とも多く, 包装から取り出した状態の安定性が担 保されている必要がある。しかしながら，すべての 錠剂同士の配合変化について組み合わせが無数に 存在するため, 組み合わせた場合の安定性をすべ て検討することは不可能である. 本研究により, メ タクリル酸コポリマーLD と Mic 40 で使用されてい
る添加物が配合変化を引き起こすことを明らかに したので，メタクリル酸コポリマーLD 含有の腸溶 錠と添加物にメグルミンを含有する医薬品との一 包化は避けるべきと考えられた. 今回の研究は錠 剂同士が融合するという配合変化のメカニズムを 解明した最初のエビデンスであり, 臨床現場にお いて, 重要な情報を提供していると考えられた.

\section{謝 辞}

本研究は JSPS 科研費 $15 \mathrm{H} 00545$ の助成を受け たものである.

\section{利益相反}

開示すべき利益相反はない.

\section{引用文献}

1）清野钽一, 服薬コンプライアンスが悪いときに はどのように対応するか, Geriatric Medicine（老 年医学) , 2014, 52, 959-964.

2）嶋村 寿, 南 優美, 村野哲雄, 三原 潔, 雪下 君子, 一包化調剂時の後発医薬品クアゼパム錠 の退色に関する検討, 日本病院薬剤師会雑誌, 2013, 49, 257-260.

3）金田達也, 大谷誠司, 高根 浩, 椎木芳和, 林原 正和, 大坪健司, 一包化調剤に押ける配合変化情 報の認識度と情報提供に伴う認識度㧍よび調剤 方法の変化, 医療薬学, 2011,37, 187-193.

4）清水幸雄, 柚原亜美, 矢野勝子, 北川佳奈子, 飯田 純一, 五十嵐信智, 伊藤清美, 落合 和, 折井孝男, 杉山 清, 簡易懸濁法におけるアルカリ性薬剤 併用時の低用量アスピリンの安定性の検討, 医 療薬学, 2010, 36, 31-36.

5) Abe T, Yanagihara $Y$, Uchino $T$, Oriyama $T$, Komatsu M, Nakajima K, Suzuki H, Evaluation of the Pharmaceutical Characteristics of Various EntericCoated Aspirin Tablets under Different Storage Conditions, Chem Pharm Bull, 2014, 62, 617-626.

6）日本医薬品添加剤協会編集, “医薬品添加物辞 典”, 薬事日報社, 東京, 2005, pp1-477. 